\title{
Diamondiferous kimberlite from Garnet Lake, West Greenland I: genesis, geochemistry and emplacement
}

\author{
M.T. Hutchison \\ Geological Survey of Denmark and Greenland, Øster Voldgade 10, DK-1350 Copenhagen K, \\ Denmark(mth@trigon-gs.com)
}

Kimberlites, ultra-mafic lamprophyres (UML), carbonatites and related rocks occur abundantly in West and South-West Greenland (Larsen and Rex, 1992). These forms of magmatism, have occurred within the Archean craton from the Archean through to the Oligocene (reviews in Larsen and Rex, 1992 and Frei et al., 2008; Secher et al., 2008).

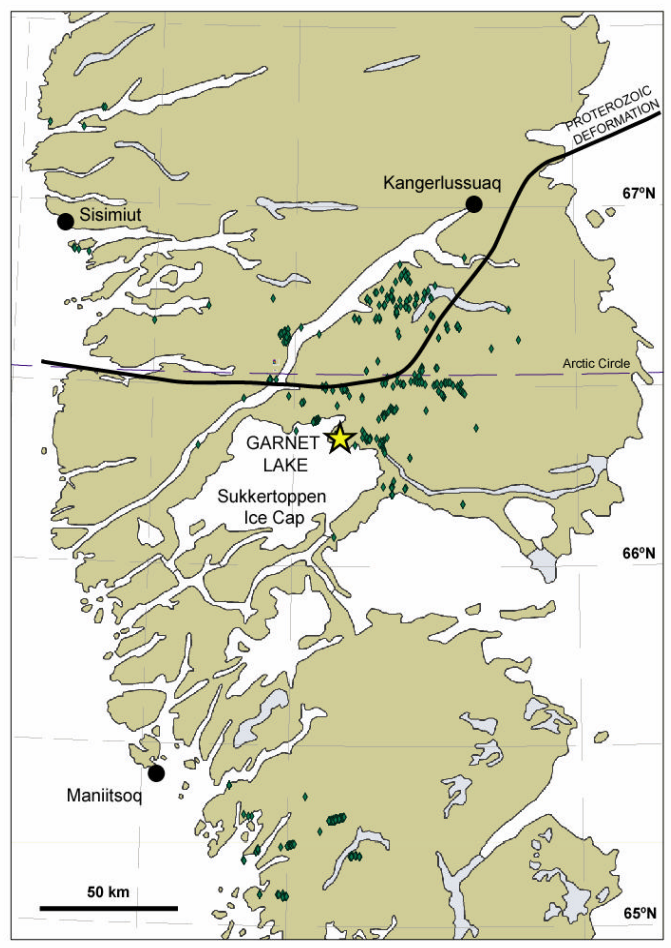

Fig. 1 Location of Garnet Lake in the context of West Greenland.

Yellow star :- Garnet Lake site; Green diamonds :- locations of in-situ kimberlitic rocks (refs. in Jensen et al., 2004); Solid black line :- boundary between undeformed Archaean (south) and rocks affected to the north by the 1.9-1.8 Ga (van Gool et al., 2002) Palaeoproterozoic Nagssugtoqidian Orogen.

Many of these intrusive bodies are of interest due to their diamond potential however the correct petrological classification of numerous diamondbearing rocks from Greenland has proven to be controversial (e.g. Mitchell et al., 1999 and Nielsen and Sand, 2008). At Garnet Lake, Sarfartoq, West Greenland (Fig. 1) a series of stacked and anastamosing dykes of kimberlite-affinity contain an abundance of high quality diamonds. The so-called Garnet Lake 'main sheet' (m.s.) distinguishes itself particularly as containing higher concentrations of diamonds than other Greenlandic diamond sources, including nearby sub-parallel sheets (Hutchison, 2005). Mantle material from the Garnet Lake m.s., including diamond, is discussed in this volume in Hutchison and Frei (2008). Here we present data relating to the host kimberlite in terms of emplacement, mineralogy, petrology, and genesis.

\section{Morphology and emplacement}

The extent of exploration work conducted so far has identified a true thickness of up to $4.25 \mathrm{~m}$ and the body (Fig. 2) has been shown, to the limits of seismic reflection techniques available, to be largely continuous for over $2.2 \mathrm{~km}$ down its $24^{\circ}$ north-easterly (True) dip. So far the sheet has been traced $1.4 \mathrm{~km}$ along its NW-SE strike (Hutchison, 2005) although given the presence of glacial cover, particularly to the north, it likely carries on past the extent proven. Drill core evidence and surface excavations demonstrate that the thickness of the body can be variable and whilst largely a single body occasionally bifurcates.

The Garnet Lake m.s. was emplaced in the late Neoproterozoic (568 Ma, Frei et al., 2008). However contact relationships, chilled margins within the main body, mineralogical and textural observations, described in the following, demonstrate that the Garnet Lake m.s. comprises of two related mineralogies.

Garnet Lake area intrusives often show clear evidence of emplacement controlled by crustal structural weaknesses such as shear zones and dykes. The Sarfartoq carbonatite complex, lying $21 \mathrm{~km}$ to the north-east of Garnet Lake occupies a major east-west structural feature. Revised age determinations demonstrate the carbonatite to be contemporaneous with kimberlitic magmatism in the area, including the Garnet Lake m.s. (Secher et al., 2008). Numerous kimberlitic sheets follow structures trending directly towards the carbonatite. Some of the structures these kimberlites occupy are pre-existing such as for the ' $\mathrm{M}$ ' and ' $\mathrm{N}$ ' kimberlitic dykes (Jensen et al., 2004), $~ 8 \mathrm{~km}$ north-west of Garnet Lake which can be traced for several kilometres along the strike of a considerably older Kangamiut dyke. However the stress on the crust during emplacement of such a large $(8-12 \mathrm{~km}$ diameter) body as the Sarfartoq carbonatite would have been considerable and undoubtedly created it's own pattern of brittle deformation. With this in mind, it is 
notable that in addition to trending directly towards the carbonatite, other bodies (Larsen, L.M., GEUS, pers. comm. 2006), including the Garnet Lake m.s. strike orthogonally to, and dip towards the carbonatite. Such a morphology is reminiscent of a cone-structure and indeed the Sarfartoq carbonatite hosts a kimberlitic intrusion within it (Jensen et al., 2004). Diamonds mostly formed increasingly over the time running up to the emplacement of the carbonatite and kimberlitic sheets (Hutchison and Frei, 2008). Furthermore, the mineralogy of the Garnet Lake m.s. also shows a carbonatitic affinity as described below.

In addition to exploitation of existing weaknesses, the Garnet Lake m.s. has also imposed its effects on its host rocks. It is common to observe significant carbonate infiltration into a network of brittle fractures within the host gneiss up to $10 \mathrm{~m}$ from even the thinner, $1 \mathrm{~m}$ pinches and this feature acts as an indicator of proximity to kimberlite during drilling.

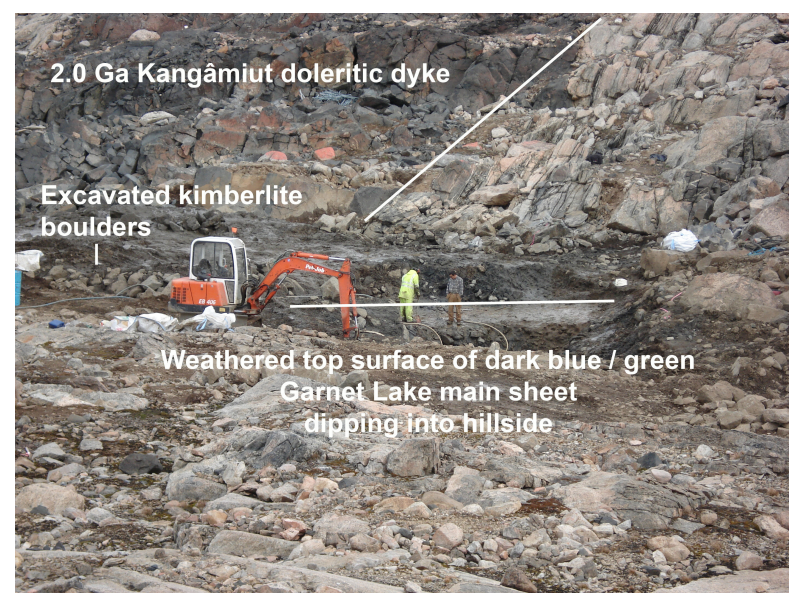

Fig. 2 The Garnet Lake main sheet.

\section{Mineral Chemistry and Petrography}

The kimberlite is hypabyssal and typically highly competent, fine grained (sub-mm) and dark green or blue. It has experienced little weathering except in areas where carbonate has been particularly abundant as a groundmass phase or in veins.

\section{Kimberlite senso lato}

The dominant rock is a carbonate-rich kimberlite senso lato and although a poorly constrained terminology, it may be termed a transitional-ultramafic lamprophyre (TransUML). It should be stressed that irrespective of the loose terminology, the rock is demonstrably diamondiferous. The texture is macrocrystal consisting $25 \%$ of mantle olivine $(<3 \mathrm{~mm})$, pyrope and phlogopite macrocrysts. The groundmass mineralogy, which primarily determines rock classification, consists of $30 \%$ opaques (mostly Mg-ilmenite and spinel) and $20 \%$ phenocrystal phlogopite. The remaining groundmass is a mixture of primary olivine, calcite, dolomite and minor phases. The rock contains a relatively large amount of ilmenite, normally attributed to a true kimberlite although core compositions are at the lower Mg-end of the kimberlitic field (11-13 wt\%
$\mathrm{MgO}$ ) and $\mathrm{Mg}$-depleted rims (down to $7 \mathrm{wt} \% \mathrm{MgO}$ ) are certainly consistent with a TransUML. The presence of chromite again suggests a TransUML affinity although compositions again have a kimberlite affinity, in this case lying between the 'Type 1 magmatic trend' of Mitchell (1995) and the 'Type 2 orangeitic trend'. Phlogopites are deep brown and strikingly zoned with unusually high $\mathrm{TiO}_{2}$ cores $(>4$ $\mathrm{wt} \% \mathrm{TiO}_{2}$ ) and tetraferri-phlogopite rims and primary diopside is present in minor quantities; both features typical of orangeites or TransUML. Groundmass olivines lie in the compositional range of $\mathrm{Mg \#}$ of 0.87 0.91 . Finally baddeleyite and apatite occur as accessory minerals and the unusual carbonatitic $\mathrm{Sr}, \mathrm{Ba}, \mathrm{Ca}-$ carbonate mineral olekminskite appears along fracture surfaces in serpentinised olivine xenocrysts.

\section{Kimberlite senso stricto}

The second component of the Garnet Lake m.s. is a kimberlite senso stricto. It is aphanitic in texture with striking fresh pyrope garnets and disaggregated olivine being the principal mantle phases. Ilmenite and perovskite comprise some $40 \%$ of the groundmass mineralogy with grains typically up to $100 \mu \mathrm{m}$. Phlogopites (15\%) are homogeneous and up to $1 \mathrm{~mm}$ in diameter and olivine phenocrysts (occasionally serpentinised) contribute $15 \%$ of volume. The remaining crystallised phases are calcite, minor dolomite and apatite. Like the kimberlite senso lato, ilmenites have high $\mathrm{Mg}$ cores (11-14 $\mathrm{wt} \% \mathrm{MgO}$ ) and Mg-depleted rims (6-7 wt\% $\mathrm{MgO}$ ). Perovskites are usually fresh but occasionally contain inclusions of baddeleyite, monazite and rutile. The high abundance of both ilmenite and perovskite is a typical characteristic of kimberlites senso stricto, as are phlogopite compositions. Phlogopites have only very thin rims which are enriched in $\mathrm{BaO}$ (up to $3 \mathrm{wt} \%$ ) and their $\mathrm{Al}$, $\mathrm{Ti}$ compositional variation lies on the kimberlitic trend.

\section{Genesis}

Nielsen and Sand (2008) argue that the carbonate-rich Majuagaa kimberlite, with the removal of olivine (based on $\mathrm{Ni}$ mass balance) and ilmenite, presents a bulk composition consistent with a melt of silicocarbonatite composition derived melt from very low degrees of partial melting of $\mathrm{CO}_{2}$-lherzolite. A similar conclusion may be invoked for Garnet Lake. Furthermore, the presence and REE characteristics of lherzolite xenocrysts recovered from Garnet Lake heavy mineral separates also support an early event of mantle fertilisation likely contributing directly to the formation of diamond (Hutchison and Frei, 2008).

The presence of two petrological components at Garnet Lake may suggest two different mantle sources. However it is proposed from ilmenite compositional gradation in the kimberlite senso stricto that the original melt was a true kimberlite with subsequent evolution of a more transitional UML component. The evolution of rock type may be linked to diamond abundance in the Garnet Lake m.s. particularly if 
variability in the $\mathrm{H}_{2} \mathrm{O} / \mathrm{CO}_{2}$ ratio is a controlling factor as favoured for similar rocks (Nielsen and Sand, 2008).

\section{Summary and Conclusions}

The Garnet Lake, diamondiferous main sheet has a temporal, geographic and chemical association with carbonate melt and the nearby Sarfartoq carbonatite complex. Multiple melt composition is evident within the sheet and it is proposed that Garnet Lake represents an evolving system from mantle fertilisation and diamond formation, initial kimberlite senso stricto melt generation evolving into a more transitional UML and associated with carbonatite.

\section{Acknowledgements}

Hudson Resources Inc. are gratefully acknowledged for sample provision and consent to publish however interpretations do not necessarily reflect the views of the company. Berit Wenzel is thanked for help with microprobe analyses. MH benefited from funding through GEUS and the European Community's 6th Framework Program, Marie Curie EIF Fellowships.

\section{References}

References are also provided in the following for the accompanying work, Extended Abstract No. 9IKC-A-00182.

Bizzarro, M., Stevenson, R.K., 2003. Major element composition of the lithospheric mantle under the North Atlantic Craton: Evidence from peridotite xenoliths of the Sarfartoq area, southwestern Greenland. Contributions to Mineralogy and Petrology, 146, 223-240.

Boyd, S.R., Kiflawi, I., Woods, G.S. 1994. The relationship between infrared absorption and the A defect concentration in diamond. Philosophical Magazine B69, 1149-1153.

Boyd, S.R., Kiflawi, I., Woods, G.S. 1995. Infrared absorption by the $\mathrm{B}$ nitrogen aggregate in diamond. Philosophical Magazine, B72, 351-361.

Brey, G.P., Köhler, T. 1990 Geothermobarometry in 4-Phase Lherzolites 2. New Thermobarometers and Practical Assessment of Existing Thermobarometers. Journal of Petrology 31, 1353-1378.

Chapman, D.S., Pollack, H.N. 1977. Regional Geotherms and Lithospheric Thickness. Geology, 5, 265-268.

Frei, D., Hutchison, M.T., Gerdes, A., Heaman, L.M. 2008. Common-lead corrected $\mathrm{U}-\mathrm{Pb}$ age dating of perovskite by laser ablation - magnetic sectorfield ICP-MS. Extended Abstracts of the 9th International Kimberlite Conference, 9IKC-A-00216.

Fujimaki, H., Tatsumoto, M., Aoki, K., 1984, Partition coefficients of $\mathrm{Hf}, \mathrm{Zr}$, and REE between phenocrysts and groundmasses. Journal of Geophysical Research, 89, Supplement B662-B672.

Grütter, H. S., Gurney, J.J., Menzies, A.H., Winter, F. 2004. An updated classification scheme for mantle-derived garnet, for use by diamond explorers. Lithos, 77, 841-857.

Hutchison, M.T., 2005. Diamondiferous kimberlites from the Garnet Lake area, west Greenland: exploration methodologies and petrochemistry. Danmarks og Grønlands Undersøgelse Rapport, 2005/68, 33-42.

Hutchison, M.T., Frei, M.T., 2008. Diamondiferous kimberlite from Garnet Lake, West Greenland II: diamonds and the mantle sample. Extended Abstracts of the 9th International Kimberlite Conference, 9IKC-A00182 .

Jensen, S.M., Secher, K., Rasmussen, T.M., Schjøth, F. 2004.
Diamond Exploration data from West Greenland: 2004 update and revision. Danmarks of Grønlands Geologiske Undersøgelse Rapport, 2004/117, DVD.

Kennedy, C., Kennedy, G. 1976. The equilibrium boundary between graphite and diamond. Journal of Geophysical Research, 81, 2467-2470.

Larsen, L.M., Rex, D.C., 1992. A review of the $2500 \mathrm{Ma}$ span of alkaline-ultramafic, potassic and carbonatitic magmatism in West Greenland. Lithos, 28, 367-402.

McDonough, W.F., Sun, S-S., 1995. The composition of the Earth. Chemical Geology, 120, 223-253.

McGregor, I.D. 1974. The system $\mathrm{MgO}-\mathrm{Al}_{2} \mathrm{O}_{3}-\mathrm{SiO}_{2}$ : Solubility of $\mathrm{Al}_{2} \mathrm{O}_{3}$ in enstatite for spinel and garnet compositions. American Mineralogist, 59, 110-119.

Mendelssohn, M.J., Milledge, H.J., 1995. Geologically significant information from routine analysis of the midinfrared spectra of diamonds. International Geology Review, 37, 95- 110.

Mitchell, R.H., 1995. Kimberlites, Orangeites and Related Rocks. Plenum, New York.

Mitchell, R.H., Scott-Smith, B.H., Larsen, L.M., 1999. Mineralogy of ultramafic dikes from the Sarfartoq, Sisimiut and Maniitsoq areas, West Greenland. Proceedings of the Seventh International Kimberlite Conference, Red Roof Design, Cape Town, 1, 574-582.

Nielsen, L.J., Hutchison, M.T., Malarkey, J., 2008. Geothermal constraints from kimberlite-hosted garnet lherzolites from southern Greenland. Extended Abstracts of the 9th International Kimberlite Conference, 9IKC-A00047.

Nielsen, T., and Sand, K. 2008. The Majuagaa kimberlite dike, Maniitsoq region, West Greenland: constraints for an Mg-rich silicocarbonatite melt composition from groundmass mineralogy and bulk compositions. Canadian Mineralogist, in press.

Sand, K.K. 2007. A geotherm for the cratonic lithospheric mantle in southern West Greenland: thermal implications for diamond potential. Unpublished Masters Thesis, University of Copenhagen.

Sand, K.K., Waight, T., Nielsen, T.D.F., Pearson, D.G., Makovicky, E., Hutchison, M.T., 2008. Four-phase geothermobarometry on mantle xenoliths from West Greenland: assessment of P/T-formulations and implications for diamond potential. Extended Abstracts of the 9th International Kimberlite Conference, 9IKC-A00146.

Secher, K., Nielsen, T.F.D., Heaman, L.M., Jensen, M.S., Schjøth, F., 2008. Emplacement patterns of kimberlites and ultramafic lamprophyres bin an alkaline province located $64-67^{\circ} \mathrm{N}$ in southern West Greenland - Evidence from 40 new, robust age analyses. Extended Abstracts of the 9th International Kimberlite Conference, 9IKC-A00173.

Stachel, T., Harris, J.W., 1997. Diamond precipitation and mantle metasomatism - evidence from the trace element chemistry of silicate inclusions in diamonds from Akwatia, Ghana. Contributions to Mineralogy and Petrology, 129, 143-154.

Taylor, W.R., Jaques, A.L., Ridd, M., 1990. Nitrogen-defect aggregation characteristics of some Australasian diamonds: Time-temperature constraints on the source regions of pipe and alluvial diamonds. American Mineralogist, 75, 1290-1320.

van Gool, J.A.M., Connelly, J.N., Marker, M., Mengel, F.C., 2002. The Nagssugtoqidian Orogen of West Greenland: tectonic evolution and regional correlations from a West Greenland perspective. Canadian Journal of Earth Sciences, 39, 665-686. 